\title{
Metabolic state of the pancreas affects end-point titre in the islet cell antibody assay
}

\author{
D. K. McCulloch ${ }^{2}$, H. Barmeier ${ }^{2}$, J.L. Neifing ${ }^{2}$ and J. P. Palmer ${ }^{1,2}$ \\ ${ }^{1}$ Department of Veterans Affairs and ${ }^{2}$ Department of Medicine, University of Washington, Seattle, Washington, USA
}

\begin{abstract}
Summary. Quantification of islet cell antibodies is used increasingly to evaluate pre-clinical Type 1 (insulin-dependent) diabetes mellitus. If expression of the antigen(s) reacting with islet cell antibodies varies depending upon the functional state of the pancreatic islets, this may partly explain differences in assay sensitivity between laboratories. To address this question we altered Beta-cell function in OsbornMendel rats, by dietary manipulation prior to killing. Rats were fed chow $(n=7)$ or a high sucrose/high fat "cafeteria" $\operatorname{diet}(n=8)$ or were fasted for $18 \mathrm{~h}(n=6)$ until immediately prior to killing. Using frozen sections of these rat pancreata in the indirect immunofluorescent test for islet cell antibodies, we determined the end-point titre for 18 sera in which islet cell antibodies had been previously quantified in our stan-
\end{abstract}

dard human pancreas assay. These sera included ten positive sera and eight normal negative control sera. The four most strongly positive sera gave significantly higher end-point titres on "cafeteria" diet-fed pancreata and lower titres on fasted pancreata $(p<0.04$ to 0.002$)$. None of non-diabetic control sera were positive on any substrate. These data suggest that islet antigen expression is increased when Beta-cell function is increased by dietary manipulation. Improved sensitivity in the islet cell antibody assay might be possible by altering Beta-cell function before or immediately after pancreas collection.

Key words: Immunology, islet cell antibody, metabolic state, rat, Beta-cell function.
Quantification of islet cell antibodies (ICA), measured by indirect immunofluorescence on snap-frozen pancreatic substrate, is used increasingly to evaluate individuals during the pre-clinical period of Type 1 (insulin-dependent) diabetes mellitus [1]. Large differences in assay results have been observed between laboratories [2], despite attempts to standardize assays by expressing results in comparison to a standard ICA positive serum and reporting the results in Juvenile Diabetes Foundation units (JDF units) [3-5]. Even when methodology is standardized within one laboratory, differences in ICA detection can be found both between and within species [6]. It is possible that some of this variation is due to differences in the functional state of the pancreatic islets at the time of collection and freezing, since this has been shown to alter protein biosynthesis [7, 8] and islet antigen expression [9-11].

We have therefore tested whether dietary manipulation in vivo will cause sufficient alteration in the functional state of the pancreatic islets to cause differences in the sensitivity of the ICA assay.

\section{Materials and methods}

Female Osborne-Mendel rats (100 g matched starting weights) were housed in individual hanging cages and were fed in one of three ways prior to killing and pancreas collection.
Fasted $(n=6)$. These animals were fed rat-chow ad libitum for 6-8 weeks but underwent an 18 -h fast prior to killing.

Chow-fed $(n=7)$. These animals were fed rat-chow ad libitum for 6-8 weeks, until just prior to killing.

"Cafeteria"-diet $(n=8)$. These animals were fed rat-chow ad libitum with the addition of high caloric density snacks and drinks including biscuits, sweets, chocolate bars, nuts, cheese, sweetened condensed milk, sweetened fruit juice, and crackers. A variety of textures and tastes were provided, in quantities to allow the rats to consume as much as they wanted, for 6-8 weeks, until just prior to killing.

\section{Pancreatic collection}

Rats were anaesthetized with intraperitoneal ketamine $(0.1 \mathrm{mg} / \mathrm{g})$, weighed and decapitated. Neck blood was collected for glucose and insulin. The pancreata were quickly removed, cut into squares $(0.5 \times 0.5 \mathrm{~cm})$ and immediately "snap-frozen" in isopentane and cooled using a bath of solid $\mathrm{CO}_{2}$ in acetone. They were then stored at $-70^{\circ} \mathrm{C}$ until sectioned. Sections were taken throughout the pancreas, using head, body, and tail in a random manner.

\section{Sera}

Eighteen sera were used; two newly diagnosed Type 1 diabetic patients, eight first-degree relatives of Type 1 diabetic subjects, and eight non-diabetic control subjects. Details of the subjects and firstdegree relatives are shown in Table 1 . All of the subjects had previously been tested using human pancreatic substrate and the ICA 
Table 1. Information regarding sera used in the study

\begin{tabular}{llllll}
\hline Serum & Description & \multicolumn{1}{l}{$\begin{array}{l}\text { ICA } \\
\text { (JDF units) }\end{array}$} & IAA $64 \mathrm{KA}$ \\
\hline 1 & $\begin{array}{l}\text { Newly diagnosed Type 1 (insulin- } \\
\text { dependent) diabetic subject }\end{array}$ & 640 & & \\
2 & $\begin{array}{l}\text { Newly diagnosed Type } 1 \text { diabetic } \\
\text { subject }\end{array}$ & 640 & & \\
3 & Sibling of Type 1 diabetic subject & 160 & + & + \\
4 & Parent of Type 1 diabetic subject & 160 & + & + \\
5 & Sibling of Type 1 diabetic subject & 80 & - & + \\
6 & Parent of Type 1 diabetic subject & 80 & - & - \\
7 & Sibling of Type 1 diabetic subject & 40 & + & + \\
8 & Sibling of Type 1 diabetic subject & 40 & - & - \\
9 & Sibling of Type 1 diabetic subject & 20 & - & + \\
10 & Parent of Type 1 diabetic subject & 20 & - & - \\
\hline
\end{tabular}

$\overline{\mathrm{ICA}}=$ islet cell antibodies; IAA $=$ insulin autoantibodies; $64 \mathrm{KA}=$ antibodies to the $64000-\mathrm{M}_{\mathrm{r}}$ islet antigen

Table 2. Differences in weight, plasma insulin, and plasma glucose in rats at killing

\begin{tabular}{lccc}
\hline & $\begin{array}{l}\text { "Cafeteria" diet } \\
(n=8)\end{array}$ & $\begin{array}{l}\text { Chow-fed } \\
(n=7)\end{array}$ & $\begin{array}{l}\text { Fasted } \\
(n=6)\end{array}$ \\
\hline Body weight $(\mathrm{g})$ & $350 \pm 13^{\mathrm{a}}$ & $294 \pm 5$ & $287 \pm 6$ \\
Plasma IRI (pmol/1) & $432 \pm 49^{\mathrm{b}, \mathrm{c}}$ & $317 \pm 38$ & $237 \pm 38$ \\
Plasma glucose (mmol/) & $7.7 \pm 0.6$ & $6.8 \pm 0.2$ & $6.5 \pm 0.2$ \\
\hline
\end{tabular}

${ }^{\mathrm{a}} p<0.05$ vs fasted animals, Mann-Whitney U-test; ${ }^{\mathrm{b}} p<0.03$, Kruskal-Wallis ANOVA; ${ }^{c} p<0.02$ vs fasted animals, Mann-Whitney U-test. IRI = immunoreactive insulin

titre of those found to be positive is given in JDF units. Subjects were also tested for the presence of insulin autoantibodies (IAA) using a sensitive liquid phase radiobinding assay including acid charcoal extraction and cold-insulin displacement $[12,13]$, and for the presence of antibodies to the $M_{r} 64000$ islet antigen (64 KA) using electrophoresis of metabolically labelled dog islets, immunoprecipitation and densitometric scanning [14]. Three subjects were positive for all three autoantibodies, two were ICA and $64 \mathrm{KA}$ positive, one was ICA and IAA positive, and four were ICA positive alone. The eight non-diabetic control subjects were negative for all three antibodies.

To minimize possible error attributable to dilution or repeated freeze/thawing, an initial $10 \mathrm{ml}$ of each serum was diluted (from 1:1 to 1:2048). Twenty-one aliquots were made from each dilution and were stored together at $-20^{\circ} \mathrm{C}$. Each aliquot was thawed once only.

\section{Assay methodology}

Cryostat sections ( $4 \mu \mathrm{m}$ thick) were placed onto gelatin-coated slides, one section per slide, and kept at $-70^{\circ} \mathrm{C}$ until use. Slides were thawed and air-dried for $30 \mathrm{~min}$ prior to use. Sera were pre-incubated for $10 \mathrm{~min}$ with $10 \mathrm{mg}$ of rat liver powder. After centrifugation for $2 \mathrm{~min}$ at $14000 \mathrm{rev} / \mathrm{min}$, using an Eppendorf microfuge, Model No. 5415 (Brinkmann Instruments, Westbury, NY, USA), $50 \mu 1$ of each test serum dilution was applied to individual slides, which were then incubated in a covered humid chamber for $30 \mathrm{~min}$ at room temperature. Slides were then rinsed three times ( 5 min each) in phosphate-buffered $0.9 \% \mathrm{NaCl}$. Seventy-five $\mu \mathrm{l}$ of goat antihuman IgG conjugated with FITC (1:80 dilution) was then applied to each section and incubated for a further $30 \mathrm{~min}$. Slides were rinsed again three times, (5 min each) and mounted using glycerol and a coverslip. Two slides were prepared for each dilution of every sera including positive and negative controls. Slides were coded, randomly rear- ranged and were read blind by two independent observers using a Nikon episcopic fluorescent microscope at $200 \times$ magnification. Each slide was recorded as positive or negative before breaking the code and comparing the results from both readers.

Our laboratory participates in the Immunology and Diabetes Workshops and proficiency testing programme, sponsored by the Juvenile Diabetes Foundation. The lower detection limit of our assay is $10 \mathrm{JDF}$ units, with a rating of $100 \%$ for laboratory consistency and laboratory specificity and $81 \%$ for laboratory sensitivity, when using human substrate.

All 21 rat pancreata were coded and used blind so that neither reader knew which pancreatic substrate was being used in each assay.

Plasma insulin was assayed by a modification of the double antibody method of Morgan and Lazarow [15]. Plasma glucose was measured using a glucose analyzer (Beckman Instruments, Palo Alto, Calif., USA).

\section{Statistical analysis}

Non-parametric statistics were used throughout using the Statview II program (Abacus Concepts Inc., Berkeley, Calif., USA, 1987) on a Macintosh SE/30 computer. Comparison between any two groups was tested using the Mann-Whitney U-test, while for all three groups the Kruskal-Wallis one-way analysis of variance was employed. Results are given as mean \pm SEM.

\section{Results}

Body weight, plasma insulin and plasma glucose for rats at the time of pancreas collection are shown in Table 2. Cafeteria-diet fed animals were significantly heavier than fasted animals ( $350 \pm 13$ vs $287 \pm 6 \mathrm{~g}, p<0.05$ ) and had significantly higher plasma insulin levels (432 \pm 49 vs $237 \pm 38 \mathrm{pmol} / \mathrm{l}, p<0.02$ ). Plasma insulin also varied significantly between the three groups $(p<0.03)$.

Mean reciprocal end-point titre for sera 1 to 10 are shown in Table 3. The four most strongly ICA positive sera ( 1 to 4 ) give significantly higher reciprocal end-point titres on pancreata from cafeteria-fed animals, intermediate results on chow-fed animals and lowest results on fasted animals (Fig. 1). Three other ICA positive sera (5, 8 and 10) showed a similar trend but failed to reach statistical significance, while the remaining three $(6,7$ and 9) were ICA negative on all rat pancreata. None of the non-

Table 3. Mean reciprocal end-point titre for ICA-positive sera on pancreatic substrate from rats fed "cafeteria" diet, chow, or fasted for $18 \mathrm{~h}$

\begin{tabular}{llllrl}
\hline Serum & $\begin{array}{l}\text { ICA } \\
\text { (JDF Units }{ }^{\mathrm{a}} \text { ) }\end{array}$ & \multicolumn{1}{l}{ "Cafeteria" } & Chow-fed Fasted & $p^{\mathrm{b}}$ \\
\hline 1 & 640 & $256 \pm 86$ & $75 \pm 11$ & $52 \pm 26$ & $<0.04$ \\
2 & 640 & $144 \pm 26$ & $34 \pm 8$ & $14 \pm 4$ & $<0.001$ \\
3 & 160 & $60 \pm 11$ & $22 \pm 5$ & $10 \pm 2$ & $<0.002$ \\
4 & 160 & $33 \pm 14$ & $14 \pm 5$ & $5 \pm 1$ & $<0.02$ \\
5 & 80 & $24 \pm 7$ & $6 \pm 2$ & $10 \pm 5$ & $\mathrm{NS}$ \\
6 & 80 & $0 \pm 0$ & $0 \pm 0$ & $0 \pm 0$ & $\mathrm{NS}$ \\
7 & 40 & $0 \pm 0$ & $0 \pm 0$ & $0 \pm 0$ & $\mathrm{NS}$ \\
8 & 40 & $4 \pm 2$ & $1 \pm 1$ & $1 \pm 1$ & NS \\
9 & 20 & $0 \pm 0$ & $0 \pm 0$ & $0 \pm 0$ & NS \\
10 & 20 & $9 \pm 4$ & $3 \pm 2$ & $1 \pm 1$ & NS \\
\hline
\end{tabular}

${ }^{a}$ Using human pancreas; ${ }^{\mathrm{b}}$ Kruskal-Wallis ANOVA.

ICA = islet cell antibodies; JDF = Juvenile Diabetes Foundation 


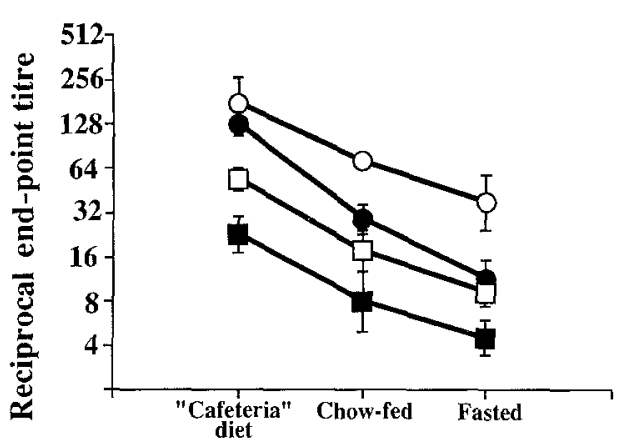

Fig. 1. Mean $( \pm S E M)$ reciprocal end-point titre for sera $1(\mathrm{O}-\mathrm{O})$, $2(-0), 3(\square-\square)$ and $4(\square-\square)$ when tested on pancreata from rats fed "cafeteria" diet, chow, or fasted for $18 \mathrm{~h}$

diabetic control subjects were found to be consistently ICA positive on any substrate.

\section{Discussion}

We have shown that the ICA assay sensitivity is increased in rats fed a high calorie cafeteria diet up until the time of killing and is decreased in rats fasted for $18 \mathrm{~h}$ prior to killing. That these dietary manipulations resulted in altered islet function at the time of pancreatic collected is shown by the differences in plasma insulin levels at killing.

It has been shown that when pancreatic Beta-cell activity is increased experimentally by electrolytic lesion of the ventral medial hypothalamus [16], by in vivo administration of phentolamine [17], or by preculturing islets in $11.1 \mathrm{mmol} / \mathrm{l}$ compared to $5.6 \mathrm{mmol} / 1$ glucose [18], such islets are more susceptible to the toxic effect of streptozotocin. Mice with the ob gene, or mice treated with glucocorticoids for goldthioglucose develop Beta-cell hyperplasia and have increased susceptibility to encephalomyocarditis, virus-induced diabetes $[19,20]$. Conversely, decreased Beta-cell activity confers protection against Beta-cell destruction. In rats transplanted with insulinoma tissue and subsequently injected with alloxan, preferential destruction of the functioning insulinoma tissue occurs; whereas, the "resting" endogenous Beta-cells are protected [21]. In both the NOD mouse and the BB rat, early insulin treatment markedly reduces the development of insulitis and subsequent diabetes $[22,23]$, and aggressive insulin therapy in newly diagnosed human Type 1 diabetic subjects results in increased remission, improved Beta-cell function and better metabolic control [24]. These studies suggest that antigen expression by pancreatic Beta-cells can be altered by altering the functional state of the Beta-cell. This has been shown directly using specific monoclonal antibodies directed against antigens in rat islets cultured at different glucose concentrations [9]. The expression of the $64000-\mathrm{M}_{\mathrm{r}}$ islet antigen is also increased when islets are cultured in high glucose concentration [10] while expression of ganglioside and other islet antigens is suppressed in rats after transplantation of rat insulinomas [11]. Logothetopoulis et al. have shown that the incorporation of labelled leucine and tryptophan into Beta-cell proteins in rats can be rapidly reduced by insulin-induced hypoglycaemia, or can be increased six- to ten-fold by glucose infusion [7]. Giddings et al. showed that starvation markedly lowers proinsulin mRNA in rats but that three- to four-fold increases occurred following glucose injection [8]. These effects were measurable $2 \mathrm{~h}$ after glucose injection and were largely completed by $12 \mathrm{~h}$. These studies suggest that protein biosynthesis and antigen expression can be rapidly altered in Beta-cells by changes in the glucose levels perfusing the islets. Our study did not evaluate how rapidly the changes in pancreatic sensitivity for ICA develop, but the studies cited above suggest that it may occur within $12 \mathrm{~h}$.

The target antigens for cytoplasmic islet cell antibodies are not known. Two autoantigens, insulin [7] and glutamic acid dehydroxylase [25] have been identified, the latter probably identical to the $64000-\mathrm{M}_{\mathrm{r}}$ antigens. However, ICA are frequently detected in individuals in whom IAA and $64 \mathrm{KA}$ are undetectable. The sera we tested were positive for ICA alone, for ICA and IAA, for ICA and $64 \mathrm{KA}$ and for all three autoantibodies. An increase in the reciprocal end-point titre on cafeteria-diet rat pancreas was statistically significant only in the four sera with the highest titre of ICA [1-4], including one serum which was negative for IAA and $64 \mathrm{KA}$. However, it is possible that glutamic acid decarboxylase and gangliosides are among the Beta-cell antigens whose expression is modulated by fasting or feeding $[10,11]$. Studies to evaluate this directly are ongoing in our laboratory. Serum 7 , positive for all three autoantibodies, serum 9 (both ICA and $64 \mathrm{KA}$ positive) and serum 6 (ICA positive at $80 \mathrm{JDF}$ units) were not detected as ICA positive on any substrate. This may be due to the fact that, in our laboratory using this methodology, rat substrate is less sensitive than human or nonhuman primate [6].

This study may have some practical implications for collection and preparation of pancreata for use in the ICA assay. Although it is unclear how quickly the changes in pancreatic function can be induced, it is possible that giving a glucose infusion before or immediately after pancreas collection might improve ICA detection when using this tissue.

Acknowledgements. This work was supported by National Institutes of Health grants DK40627, DK02450, and DK33873 and by the Department of Veterans Affairs. We are grateful to Drs. D.F.Lattermann and S.C.Woods for providing the animals, to Professor A. Lernmark for helpful comments, to Ms. P.Israel, Ms. R. Parks, and Ms. J. Watters for technical assistance, and to Ms. L. Spivey for word processing.

\section{References}

1. McCulloch DK, Palmer JP (1989) Early diagnosis of type I diabetes mellitus. Diab Nutr Metab 2:245-255

2. Bottazzo GF, Gleichmann H (1986) Immunology and diabetes workshops: report of the first international workshop on the standardization of cytoplasmic islet cell antibodies. Diabetologia 29: $125-126$

3. Gleichmann H, Bottazzo GF (1987) Progress towards standardization of cytoplasmic islet-cell antibody assay. Diabetes 36 : $578-584$

4. Bonifacio E, Lernmark $\AA$, Dawkins RL (1988) Serum exchange and use of dilutions have improved precision of measurement of islet cell antibodies. J Immunol Meth 106: 83-87

5. Boitard C, Bonifacio E, Bottazzo GF, Gleichmann H, Molenaar J (1988) Immunology and diabetes workshop: report on the 
third international (stage 3) workshop on the standardization of cytoplasmic islet cell antibodies. Diabetologia 31: 451-452

6. Mozaffarian N, McCulloch DK, Palmer JP (1991) Non-human pancreas as substrate for cytoplasmic islet cell antibodies. Diab Res Clin Pract 11: 33-39

7. Logothetopoulos J, Jain K (1980) In vivo incorporation of $\left[{ }^{3} \mathrm{H}\right]$ leucine and $\left[{ }^{3} \mathrm{H}\right]$ tryptophan into proinsulin-insulin and other islet cell proteins in normoglycemic, hyperglycemic, and hypoglycemic rats. Diabetes 29: 801-805

8. Giddings SJ, Chirgwin J, Permutt MA (1982) Effects of glucose on proinsulin messenger RNA in rats in vivo. Diabetes 31: $624-629$

9. Aaen K, Rygaard J, Josefsen K, Petersen H, Brogren C-H, Horn T, Buschard K (1990) Dependence of antigen expression on functional state of B-cells. Diabetes 39: 697-701

10. Kampe O, Andersson A, Bjork E, Hallberg A, Karlsson FA (1989) High-glucose stimulation of $64000-\mathrm{Mr}$ islet cell autoantigen expression. Diabetes 38: 1326-1328

11. Appel MC, Dotta F, O'Neil JJ, Eisenbarth GS (1989) B-cell activity regulates the expression of islet antigenic determinants. Diabetologia 32: 461 A (Abstract)

12. Palmer JP, Asplin CM, Clemons P, Lyen K, Tatpati O, Raghu PK, Paquette TL (1983) Insulin antibodies in insulin-dependent diabetics before insulin treatment. Science 222: 1337-1339

13. Palmer JP, Asplin CM, Raghu PK et al. (1986) Anti-insulin antibodies in insulin dependent diabetics before insulin treatment a new marker for autoimmune B-cell damage? Pediat Adolesc Endocr 15: 111-116

14. Barmeier H, McCulloch DK, Neifing J, Rajotte R, Palmer JP, Lernmark $\AA$ (1990) Progression of beta cell dysfunction is associated with $64 \mathrm{~K}$ antibodies in first degree relatives of IDDM patients. Diabetes 39 [Suppl 1]: 122 A (Abstract)

15. Morgan CR, Lazarow A (1963) Immunoassay of insulin: two antibody system: plasma insulin levels of normal, subdiabetic and diabetic rats. Diabetes 12: 115-136

16. West DM, Seino Y, Woods SC, Porte Jr D (1980) Ventromedial hypothalamic lesions increase pancreatic sensitivity to streptozocin in rats. Diabetes 29:948 951
17. Talwalker PK, Kaul CL, Grewal RS (1979) Potentiation of the diabetogenic effect of streptozocin by phentolamine in the rat. J Pharm Pharmacol 31: 598-600

18. Eizirik DL, Strandell E, Sandler S (1988) Culture of mouse pancreatic islets in different glucose concentrations modified B-cell sensitivity to streptozotocin. Diabetologia 31: 168-174

19. Craighead JE (1981) Viral diabetes mellitus in man and experimental animals. Am J Med 70: 127-134

20. D'Andrea BJ, Wilson GL, Craighead JE (1981) Effect of genetic obesity in mice on the induction of diabetes by encephalomyocarditis virus. Diabetes $30: 451-454$

21. Appel MC, Chick WL, Rossini AA (1981) Sensitivity of suppressed islet B-cells to alloxan. Diabetologia 21: 243-247

22. Gotfredsen CF, Buschard K. Frandsen EK (1985) Reduction of diabetes incidence of BB Wistar rats by early prophylacticinsulin treatment of diabetes-prone animals. Diabetologia 28: 933-935

23. Atkinson MA, Maclaren NK, Luchetta R, Burr I (1990) Insulitis and diabetes in NOD mice reduced by prophylactic insulin therapy. Diabetes 39: 933-937

24. Shah SC, Malone JI, Simpson NE (1989) A randomized trial of intensive insulin therapy in newly diagnosed insulin-dependent diabetes mellitus. N Engl J Med 320: 550-554

25. Baekkeskov S, Aanstoot H-J, Cliristgau S et al. (1990) Identification of the $64 \mathrm{~K}$ autoantigen in insulin-dependent diabetes as the GABA-synthesizing enzyme glutamic acid decarboxylase. Nature 347: 151-156

Received: 18 March 1991

and in revised form: 22 May 1991

Dr. D. K. McCulloch

VA Medical Center, ZB-20

Medical Services (111)

1660 S. Columbian Way

Seattle, WA 98108

USA 